\title{
PAPER
}

Check for updates

Cite this: New J. Chem., 2018, 42,6077

Received 9th February 2018

Accepted 14th March 2018

DOI: $10.1039 / c 8 n j 00700 d$

rsc.li/njc

\section{Novel functionalized organotellurides with enhanced thiol peroxidase catalytic activity}

\author{
Damiano Tanini, (D) *a Anna Grechi, ${ }^{a}$ Lorenzo Ricci, ${ }^{a}$ Silvia Dei, ${ }^{\mathrm{b}}$ Elisabetta Teodori ${ }^{\mathrm{b}}$ \\ and Antonella Capperucci*a
}

\begin{abstract}
The thiol peroxidase-like activity of a series of novel functionalized tellurium containing catalysts has been investigated with different models. Dialkyl- and aryl-alkyl-tellurides, conveniently achieved through the ring opening of strained heterocycles, exhibited remarkable catalytic antioxidant activity, being able to reduce hydrogen peroxide in the presence of different thiols (benzenethiol, dithiothreitol and glutathione) under different conditions. The nature of the $\beta$-substituent strongly influenced the performances of the studied catalysts, thus giving useful criteria for the design of good synthetic mimics of glutathione peroxidase. The catalytic activity of functionalized organotellurides has been compared with that of their selenated analogues, showing as the latter behave as less efficient catalysts.
\end{abstract}

\section{Introduction}

Glutathione peroxidase (GPx) is a selenocysteine-containing mammalian enzyme that plays a crucial role in the protection of aerobic living cells from oxidative stress. It catalyzes the reduction of harmful hydroperoxides by using glutathione (GSH) as a reducing agent. ${ }^{1}$

The onset of a number of human diseases such as cancer, cystic fibrosis, immune disorders, atherosclerosis, Alzheimer's and Parkinson's disease has been correlated with an enhanced concentration of reactive oxygen species (ROS), due to oxidative stress. ${ }^{2}$ Taking into account the importance of glutathione peroxidase as a natural defence against oxidative stress, the design and the synthesis of novel small molecules active as catalytic antioxidants have attracted considerable interest. ${ }^{3}$

Over the past decades, after the discovery that ebselen mimics the catalytic activity of GPx, several synthetic organoselenium compounds have emerged as good GPx-like active compounds, being able to reduce peroxides using thiols as cofactors. $^{4,5}$

In recent years, besides organoselenium derivatives, the design and synthesis of Te-containing antioxidant compounds has attracted considerable attention as some of them exhibited antitumor, antibacterial, and antihelmenthic activities. ${ }^{6}$ A number of

\footnotetext{
a Dipartimento di Chimica "Ugo Schiff", Università di Firenze, Via della Lastruccia 3-13, 50019 Sesto Fiorentino, Italy.E-mail: damiano.tanini@unifi.it

${ }^{b}$ NEUROFARBA - Dipartimento di Neuroscienze, Psicologia, Area del Farmaco e Salute del Bambino, Sezione Scienze Farmaceutiche e Nutraceutiche,

Università di Firenze, Via U. Schiff 6, 50019 Sesto Fiorentino (FI), Italy

$\dagger$ Electronic supplementary information (ESI) available: General experimental procedures, synthetic details, characterization data and copy of NMR spectra of new compounds. See DOI: 10.1039/c8nj00700d
}

organotellurium derivatives have been reported as GPx mimics. ${ }^{1 c, 7}$ Diaryl tellurides ${ }^{8,9}$ and ditellurides ${ }^{10}$ have been demonstrated to exhibit thiol peroxidase activity against different thiols.

Several authors have described that substitution of selenium by tellurium in a series of diarylchalcogenides results in a pronounced increase of the catalytic antioxidant activity. ${ }^{1 c}$

The catalytic activity of 5-hydroxy-2,3-dihydroxybenzo[b]tellurophene, ${ }^{11}$ aryl-telluroamino derivatives ${ }^{12}$ and tellurium functionalised cyclodextrin ${ }^{13}$ have also been studied. On the other hand, the introduction of tellurium containing moieties onto natural compounds such as tocopherols ${ }^{14}$ and chrysin ${ }^{15}$ have been applied to increase the antioxidant activity of such structures.

Substituted dialkyl ditellurides have received less attention with respect to their diaryl analogues ${ }^{8,12,16}$ albeit their potential interest in developing new pharmacological agents. Furthermore, the promising pharmacological properties of $\mathrm{N}$ - and O-containing organochalcogens have prompted researchers to design novel heteroatom-functionalized chalcogenides. ${ }^{17}$ To the best of our knowledge, a little is known about the GPx-like properties of hydroxy- or amino-functionalized dialkyl- and aryl-alkyl-tellurides, whereas no example is reported for organotellurides bearing sulfurated moieties. ${ }^{12,18}$

During the course of our studies in selenium chemistry we disclosed novel synthetic routes to access several classes of new functionalized organoselenium derivatives through the ring opening reaction of strained heterocycles with selenosilanes. ${ }^{19,20}$ Some of these selenium-containing structures showed interesting activities as antioxidants $^{21}$ and carbonic anhydrase inhibitors. ${ }^{22}$ More recently, we extended our interest to the tellurium chemistry, finding a convenient approach to functionalized dialkyl- and aryl-alkyl-tellurides. ${ }^{23}$ Indeed, reaction of epoxides, aziridines 
and thiiranes with $\mathrm{Li}_{2} \mathrm{Te}$ leads to the smooth formation of $\beta$-hydroxy-dialkyl tellurides, $\beta$-amino-dialkyl tellurides and disubstituted 1,2,5-dithiatellurepanes through a regioselective and stereospecific ring opening route. Furthermore, $\beta$-phenyltelluroalcohols, amines and disulfides can be achieved from the above mentioned strained heterocycles by using either in situ generated $\mathrm{PhTe}^{-}$or $\mathrm{PhTeSiMe}_{3}$, through a fluoride ion mediated ring opening reaction in comparable yields. ${ }^{23}$

These methodologies might offer the possibility to design new variously functionalized biologically active molecules. ${ }^{24}$ As a part of our growing interest in the study of novel antioxidant systems, we report herein the data obtained in the investigation of the thiol-peroxidase-like activity of a series of functionalized tellurides.

\section{Results and discussion}

Organotellurides reported in Chart 1 were synthesised from three-membered heterocycles as reported in the Scheme S1 $(\mathrm{ESI} \dagger)^{23}$

The catalytic antioxidant activity of these densely functionalised organotellurium compounds as GPx model enzymes was studied according to literature reported methods using dithiothreitol, $^{25}$ benzenethiol $^{26}$ or glutathione $^{27}$ as substrates.

The catalytic thiol-peroxidase activity of compounds 1-7 was preliminary investigated following the dithiothreitol (DTT ${ }_{\text {red }}$ ) oxidation by means of ${ }^{1} \mathrm{H}$ NMR. Methanol $\left(\mathrm{CD}_{3} \mathrm{OD}\right)$ was selected as a solvent in this assay because the reaction proceeded too fast in water.

We commenced our studies with hydroxy telluride 1a. We were pleased to observe an immediate and complete oxidation of DTT, when this compound was used in catalytic amount (10 mol\% with respect to DTT). Intriguingly, the same excellent activity was retained when the test was performed with a lower concentration of $1 \mathrm{a}(1 \mathrm{~mol} \%$, Fig. 1). On the basis of these findings, the activity of a series of hydroxy tellurides (1-3) was investigated under the same conditions. As can be seen from the graph depicted in Fig. 1, symmetric $\beta$-hydroxy tellurides 1a-c exhibited a remarkable catalytic activity, promoting complete DTT oxidation within 2 min from the addition of $\mathrm{H}_{2} \mathrm{O}_{2}$. In order to evaluate the influence of the Te-containing moiety on the GPx-like activity of $\beta$-hydroxy tellurides, non-symmetric

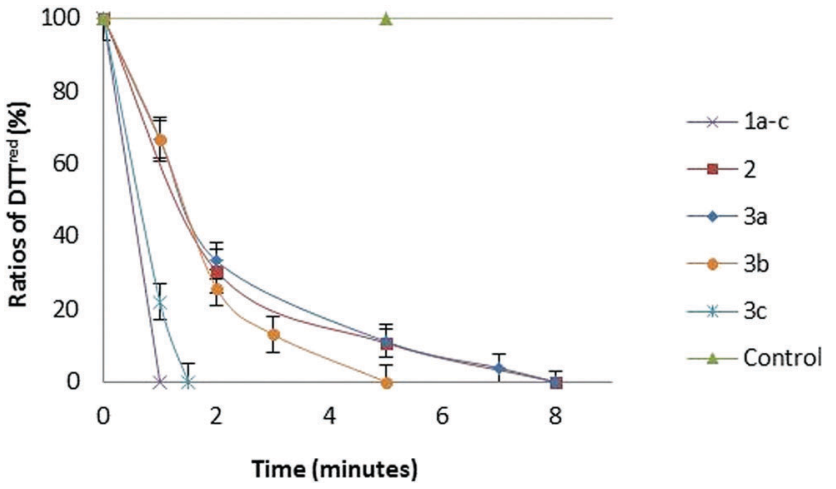

Fig. 1 Oxidation of DTT ${ }^{\text {red }}$ with $\mathrm{H}_{2} \mathrm{O}_{2}$ in the presence of Te-containing catalysts (1\%). Reaction conditions: $\left[\mathrm{DT} \mathrm{T}^{\mathrm{red}}\right]_{0}=0.14 \mathrm{mM},\left[\mathrm{H}_{2} \mathrm{O}_{2}\right]_{0}=0.14 \mathrm{mM}$, [catalyst] $=0.0014 \mathrm{mM}, \mathrm{CD}_{3} \mathrm{OD}(0.6 \mathrm{~mL})$. In the control experiment the reaction was run with no catalyst. The mean \pm SD values of three separate experiments are reported.

2-hydroxy substituted-ethyl telluride 2 and phenyl tellurides 3a,b were used as catalysts. The curves related to their efficacy are reported in Fig. 1. These compounds displayed a slightly lower activity than dihydroxy tellurides 1a-c, catalyzing the complete DTT oxidation in 5-8 min.

With the aim to enlarge the scope of the study, the $\beta$-phenyltelluro alcohol $3 \mathbf{c}$ - containing two tellurium atoms was conveniently synthesized from 1,3-butadiene diepoxide (Scheme 1) and tested under the above reported conditions. As can be noticed from Fig. 1, the thiol-peroxidase-like activity showed by $\mathbf{3 c}$ resulted about three-fold higher than $\mathbf{3 b}$.

Having explored the thiol-peroxidase-like activity of variously substituted $\beta$-hydroxy tellurides, we moved to evaluate whether such catalytic activity could be affected by the nature of the functional group present at the $\beta$ position. Thus, differently substituted tellurides $4-7$, bearing a $\beta$-amino or a $\beta$-disulfide moiety were used as catalysts in the reaction of DTT with $\mathrm{H}_{2} \mathrm{O}_{2}$. As can be

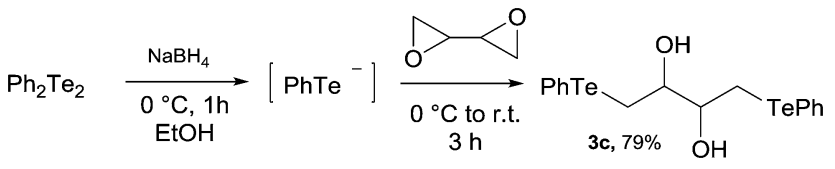

Scheme 1
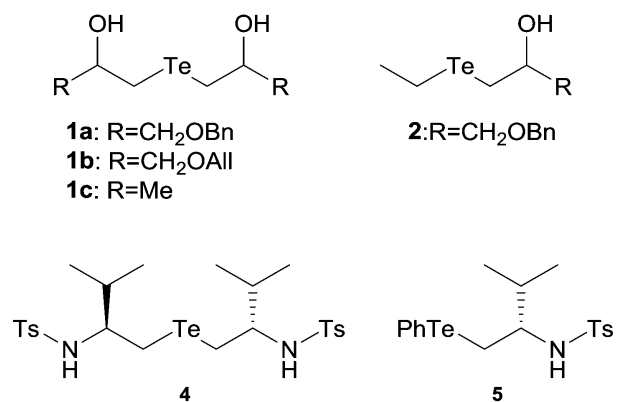
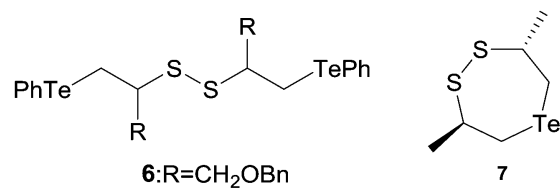

Chart 1 


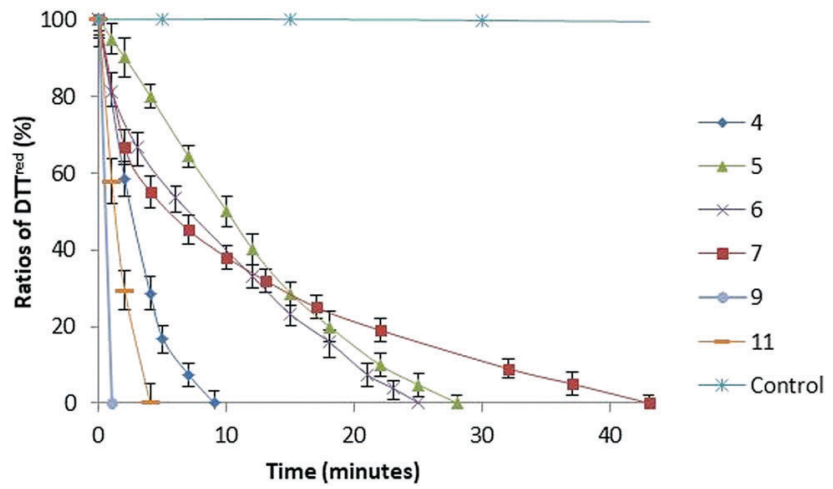

Fig. 2 Oxidation of DTT ${ }^{\text {red }}$ with $\mathrm{H}_{2} \mathrm{O}_{2}$ in the presence of Te-containing catalysts (1 mol\%). Reaction conditions: $\left[\mathrm{DTT}{ }^{\mathrm{red}}\right]_{0}=0.14 \mathrm{mM},\left[\mathrm{H}_{2} \mathrm{O}_{2}\right]_{0}=$ $0.14 \mathrm{mM}$, [catalyst] $=0.0014 \mathrm{mM}, \mathrm{CD}_{3} \mathrm{OD}(0.6 \mathrm{~mL})$. In the control experiment the reaction was run with no catalyst. The mean \pm SD values of three separate experiments are reported.

seen in the Fig. 2, the $\beta$-amino dialkyl telluride $\mathbf{4}$ behaved as the most active catalyst within this series, although the $\beta$-hydroxy substituted analogues 1a-c performed marginally better under the same conditions. On the other hand, $\beta$-phenyltelluro-amine 5 and disulfide $\mathbf{6}$ displayed a significant lower catalytic activity with respect to the corresponding $\beta$-phenyltelluro alcohols $\mathbf{3 a} \mathbf{a}, \mathbf{b}$. Besides acyclic tellurides, also dithiatellurepane 7 was tested under these conditions, exhibiting an unexpected low activity in comparison to what previously observed on cyclic selenides. ${ }^{21,25}$ The catalytic activity of various cyclic tellurides is currently under study, in order to elucidate the behaviour of this class of catalysts with respect to their acyclic and selenated analogues.

$\beta$-Phenyltelluro-amine 5 and disulfide 6 proved to be the less active compounds within the studied series. We reasoned that a possible explanation of this lower activity could be envisaged in
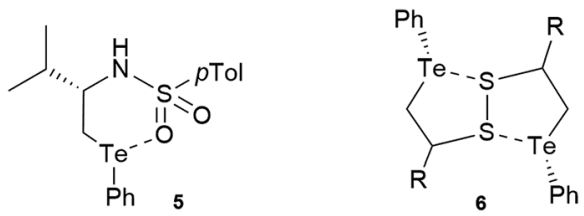

Fig. 3 Intramolecular chalcogen bonding interactions (ChB) in structures 5 and 6. the presence of chalcogen bonds between tellurium and the tosyl or the disulfide groups (Fig. 3) that could hamper the telluride oxidation or slow the rate of the thiol addition and that of the reductive elimination reaction of the intermediates involved in the thiol-peroxidase catalytic pathway. ${ }^{18,28,29}$ Thus, the observed decrease of the thiol-peroxidase properties could be related to the strength of the chalcogen-bonding interactions, originated from the $\sigma$ hole in the $\sigma^{*}$ orbital of the covalent bonds of the tellurium atom. ${ }^{30}$

In order to test this hypothesis, novel $\beta$-phenyltelluro-amine 9 and sulfide $\mathbf{1 1}$ were synthesised from the corresponding $\mathrm{N}$-Boc-protected aziridine and thiirane, following the Scheme 2. The amino telluride $\mathbf{9}$ was obtained through acetyl chloride promoted cleavage of the $N$-Boc protected phenyltelluro amine $\mathbf{8}$, arisen from a regioselective ring opening reaction of the $N$-Boc 2-isopropylaziridine with diphenyl ditelluride. $S$-Allylation of the phenyltelluro thiolate intermediate 10, efficiently achieved in situ by using allyl bromide, afforded to $\beta$-phenyltelluro sulfide $\mathbf{1 1}$.

Having synthesised novel organotellurides, where Te...O/S nonbonded interactions cannot take place, their GPx-like activity was pursued. We were pleased to find that using compounds $\mathbf{9}$ and $\mathbf{1 1}$ as catalysts under the standard conditions, complete DTT oxidation was achieved within $4 \mathrm{~min}$ and $1 \mathrm{~min}$, respectively. These findings are in accordance with the presence of $\mathrm{Te} \cdots \mathrm{O} / \mathrm{S}$ nonbonded interactions, previously reported for selenium-containing GPx catalysts, ${ }^{31}$ and might indicate a useful criterion for designing new $\beta$-functionalized tellurides highly active as GPx mimics.

On the basis of these results, having demonstrated the high catalytic activity of a series of $\beta$-functionalised tellurides in the oxidation of DTT by $\mathrm{H}_{2} \mathrm{O}_{2}$, we next turned our attention to evaluate such activity against different thiols under different conditions. Benzenethiol was thus used as a substrate and the reduction of $\mathrm{H}_{2} \mathrm{O}_{2}$ was monitored through UV absorption increase at $305 \mathrm{~nm}$, according to Tomoda's method. Results of this investigation are listed in Table 1; kinetic profiles of selected catalysts are depicted in Fig. 4 . As can be noticed, in accordance with the study on DTT oxidation, hydroxy tellurides 1a-c and $\mathbf{2}$ proved to be the most active compounds, whereas the presence of a $N$-tosyl amino group at the $\beta$ position (in 4 and 5) resulted in a poor catalyst performance.

Interestingly, according to this assay, the catalytic activity of such functionalized tellurides was found to be comparable or

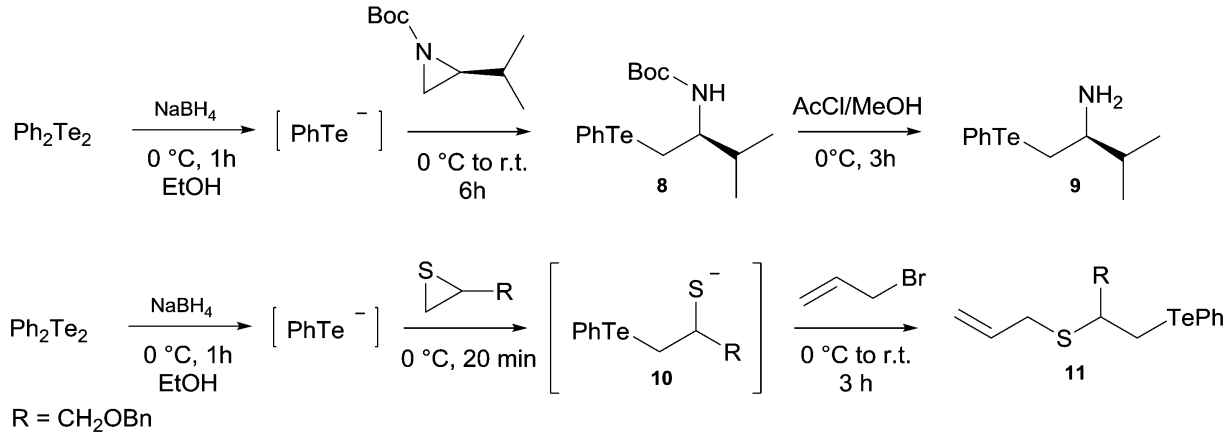

Scheme 2 
Table 1 Thiol-peroxidase like activity of functionalized organotellurides according to different methods

\begin{tabular}{lllll}
\hline Entry & Compound & DTT $\left(T_{50}\right)^{a, b}$ & PhSH $\left(T_{50}\right)^{a, c}$ & GSH/NADPH $\left(T_{50}\right)^{a, d}$ \\
\hline $\mathbf{1}$ & $\mathbf{1 a}$ & $<60$ & $235( \pm 21)$ & $<5$ \\
2 & $\mathbf{1 b}$ & $<60$ & $206( \pm 24)$ & $<5$ \\
3 & $\mathbf{1 c}$ & $<60$ & $224( \pm 32)$ & $<5$ \\
4 & $\mathbf{2}$ & $90( \pm 13)$ & $68( \pm 16)$ & $<5$ \\
$\mathbf{5}$ & $\mathbf{3 a}$ & $92( \pm 10)$ & $426( \pm 35)$ & $9( \pm 3)$ \\
6 & $\mathbf{4}$ & $214( \pm 34)$ & $1007( \pm 63)$ & $9( \pm 2)$ \\
7 & $\mathbf{5}$ & $600( \pm 61)$ & n.d. & $14( \pm 3)$ \\
8 & $\mathbf{7}$ & $498( \pm 53)$ & $780( \pm 72)$ & n.d. \\
9 & $\mathbf{9}$ & $<60$ & n.d. & $<5$ \\
10 & $\mathbf{1 1}$ & $82( \pm 16)$ & n.d. & $<5$
\end{tabular}

${ }^{a} T_{50}$ is the time required, in seconds, to reduce the initial thiol concentration with $50 \%$ after the addition of $\mathrm{H}_{2} \mathrm{O}_{2}$; data in parenthesis are the experimental error. ${ }^{b}$ DTT oxidation was monitored by the mean of ${ }^{1} \mathrm{H}$ NMR spectroscopy; $1 \mathrm{~mol} \%$ of catalyst with respect to the thiol was used. ${ }^{c}$ Diphenyl disulfide formation was monitored by UV spectroscopy $(305 \mathrm{~nm}) ; 2.6 \mathrm{~mol} \%$ of catalyst with respect to the thiol was used. ${ }^{d} \mathrm{NADPH}$ consumption was monitored by UV spectroscopy $(340 \mathrm{~nm})$; $6 \mathrm{~mol} \%$ of catalyst with respect to GSH was used.
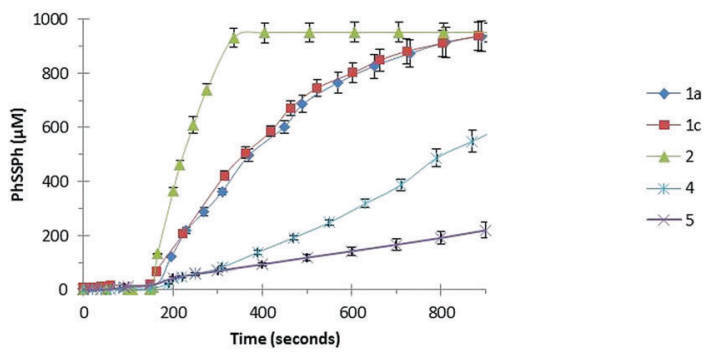

Fig. 4 PhSH oxidation GPx assay. Reaction conditions: $[\mathrm{PhSH}]_{0}=1.9 \mathrm{mM}$, $\left[\mathrm{H}_{2} \mathrm{O}_{2}\right]_{0}=8.8 \mathrm{mM}$, [catalyst] $=0.05 \mathrm{mM}$ in methanol $(2 \mathrm{~mL})$ at ambient temperature. The mean \pm SD values of three separate experiments are reported.

higher with respect to literature reported data on tellurium containing compounds under the same experimental conditions. ${ }^{12}$

In order to verify the activity of such compounds in experimental conditions closer to the physiological one, we considered to apply the GSH/GR coupled test ${ }^{27}$ that better reproduces the cellular environment. The curves related to the kinetic profile of $\mathrm{NADPH}$ consumption for selected compounds are reported in Fig. 5. All the evaluated Te-containing catalysts behaved as mimics of GPx under these conditions; $\beta$-hydroxy tellurides $\mathbf{1 a - c}$ and 2 exhibited the highest activity, being NADPH oxidation complete in 5-10 s from the addition of $\mathrm{H}_{2} \mathrm{O}_{2}$. In line with the kinetic studies on dithiothreitol oxidation, a slightly lower activity was found for $\beta$-hydroxy phenyltelluride 3a and $\beta$-amino-dialkyl telluride 4.

Furthermore, significantly higher catalytic activity of the free amino $\beta$-phenyltelluride 9 with respect to the $N$-Tosyl protected analogue 5 was also found carrying out the GSH/GR coupled test, thus confirming that the substituent at the $\beta$-position is an important factor that needs to be taken into account for the design of powerful catalytic antioxidants.

Having explored the catalytic activity of differently substituted and functionalized organotellurides, we synthesised some selenium-containing anologues ${ }^{19,22 a}$ with the aim to

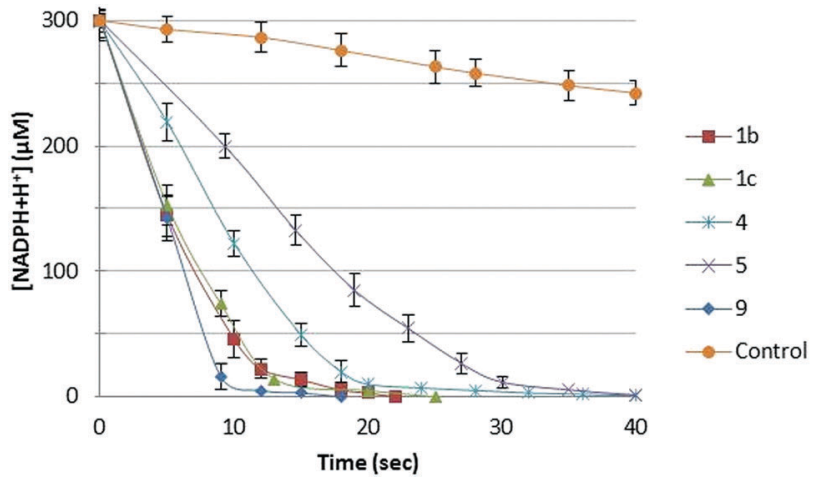

Fig. $5 \mathrm{NADPH}$-coupled GPx assay. Reaction conditions: $[\mathrm{NADPH}]_{0}=$ $0.3 \mathrm{mM},[\mathrm{GSH}]_{0}=1.0 \mathrm{mM},\left[\mathrm{H}_{2} \mathrm{O}_{2}\right]_{0}=2.5 \mathrm{mM},[\mathrm{GR}]=4$ units per $\mathrm{mL}$, [catalyst] $=0.066 \mathrm{mM}$ in $\mathrm{pH} 7.4$ phosphate buffer at ambient temperature. The mean \pm SD values of three separate experiments are reported.

Table 2 Comparison of the thiol peroxidase activity of $\beta$-hydroxy tellurides with their selenium containing analogues

\begin{tabular}{|c|c|c|c|c|}
\hline \multirow[b]{2}{*}{ Entry } & \multicolumn{2}{|c|}{$\begin{array}{l}\text { 1: } Y=T e \\
12: Y=S e\end{array}$} & \multicolumn{2}{|c|}{$\begin{array}{l}\text { 3: } \mathrm{Y}=\mathrm{Te} \\
\text { 13: } \mathrm{Y}=\mathrm{Se}\end{array}$} \\
\hline & Catalyst $^{a}$ & $\mathrm{Y}$ & $\mathrm{R}$ & $T_{50}^{b}$ \\
\hline 1 & $1 a$ & $\mathrm{Te}$ & $\mathrm{CH}_{2} \mathrm{OBn}$ & $<60$ \\
\hline 2 & $1 b$ & $\mathrm{Te}$ & $\mathrm{CH}_{2} \mathrm{OAll}$ & $<60$ \\
\hline 3 & $3 a$ & $\mathrm{Te}$ & $\mathrm{CH}_{2} \mathrm{OBn}$ & $92( \pm 10)$ \\
\hline 4 & $3 \mathbf{b}$ & $\mathrm{Te}$ & $\mathrm{Me}$ & $88( \pm 15)$ \\
\hline 5 & $12 a$ & $\mathrm{Se}$ & $\mathrm{CH}_{2} \mathrm{OBn}$ & $3246( \pm 256)$ \\
\hline 6 & $12 b$ & $\mathrm{Se}$ & $\mathrm{CH}_{2} \mathrm{OAll}$ & $2868( \pm 211)$ \\
\hline 7 & $13 a$ & $\mathrm{Se}$ & $\mathrm{CH}_{2} \mathrm{OBn}$ & $328( \pm 34)$ \\
\hline 8 & $13 b$ & $\mathrm{Se}$ & $\mathrm{Me}$ & $297( \pm 28)$ \\
\hline
\end{tabular}

${ }^{a}$ Catalysts concentration used for the test: tellurides ( $\left.1 \mathrm{~mol} \%\right)$, selenides (10 mol\%). ${ }^{b} T_{50}$ is measured in seconds; data in parenthesis are the experimental error.

evaluate the effect of these two chalcogen atoms on the catalytic efficiency. Results of this study on dithiothreitol oxidation are shown in Table 2. As reported for other classes of chalcogencontaining compounds, ${ }^{1 c}$ the replacement of tellurium with selenium brought about a dramatic decrease in the thiolperoxidase activity.

\section{Conclusions}

In this study, the thiol-peroxidase activity of a series of novel functionalized tellurium containing catalysts has been evaluated towards different substrates. Although all the synthesised compounds exhibited remarkable catalytic activity, the results showed that the nature of the groups close to the tellurium, rather than the alkyl or aryl substituent directly bound to the Te center, represents an important factor in order to achieve higher catalytic efficiency. The thiol peroxidase-like activity of the tested organotellurides proved to be much higher with respect to that of their selenium-containing analogues. Further studies on the synthesis, the reactivity and the application of 
tellurium containing molecules, as well as the evaluation of their toxicity is currently ongoing in our laboratories.

\section{Experimental}

\section{General}

${ }^{1} \mathrm{H}$ and ${ }^{13} \mathrm{C}$ NMR spectra were recorded in $\mathrm{CDCl}_{3}$ with a Varian Mercury Plus instrument or with a Varian INOVA instrument at 400 and $100 \mathrm{MHz}$, respectively. The corresponding residual non-deuterated solvent was used as a reference (726 ppm for ${ }^{1} \mathrm{H}$ and $77.0 \mathrm{ppm}$ for ${ }^{13} \mathrm{C}$ ). ${ }^{125} \mathrm{Te}$ NMR spectra were recorded in $\mathrm{CDCl}_{3}$ at $126 \mathrm{MHz}$ with a Bruker Ultrashield 400 Plus instrument. (PhTe $)_{2}$ was used as an external reference $(\delta=420 \mathrm{ppm})$. ${ }^{1} \mathrm{H}$ NMR data are reported as follows: chemical shift, integration, multiplicity ( $\mathrm{s}=$ singlet, $\mathrm{bs}=$ broad singlet, $\mathrm{d}=$ doublet, $\mathrm{t}=$ triplet, $\mathrm{m}=$ multiplet, $\mathrm{dd}=$ doublet of doublet, etc. ), coupling constant $(J)$ or line separation (ls), and assignment. Mass spectra (MS) were determined by ESI. All the reactions were performed under a positive pressure of nitrogen and were monitored by TLC using commercially available precoated plates (silica gel 60 F 254) and compounds were visualised by fluorescence quenching or by staining the plates with acidic $p$-anisaldehyde solution. Silica gel 60, 230-400 mesh, was used for flash column chromatography. Dry solvents were obtained using a Pure Solv ${ }^{\mathrm{TM}}$ Micro system. Commercially available reagents were used as obtained from freshly opened containers without further purification. Thiiranes ${ }^{32}$ and aziridines ${ }^{33}$ were synthesised according to literature procedures. Organotellurides 1-7 were achieved from strained heterocycles following reported procedures (Scheme S1, ESI $\dagger$ ). ${ }^{23}$

1,4-Bis(phenyltellanyl)butane-2,3-diol (3c). $\mathrm{NaBH}_{4}(28 \mathrm{mg}$, $0.75 \mathrm{mmol}, 3.0$ eq.) was portionwise added to a solution of diphenyl ditelluride (102 $\mathrm{mg}, 0.25 \mathrm{mmol}, 1.0$ eq.) in EtOH $(2 \mathrm{~mL})$ at $0{ }^{\circ} \mathrm{C}$ under inert atmosphere $\left(\mathrm{N}_{2}\right)$. After $30 \mathrm{~min}$, 2,2'-bioxirane (24 mg, $0.275 \mathrm{mmol}, 1.1 \mathrm{eq}$.) was slowly added and the reaction mixture was warmed at RT and stirred for $3 \mathrm{~h}$ (reaction progress monitored by TLC). Afterwards, saturated aq. $\mathrm{NH}_{4} \mathrm{Cl}(3 \mathrm{~mL})$ was added and the organic phase was extracted with $\mathrm{Et}_{2} \mathrm{O}(2 \times 5 \mathrm{~mL})$, washed with brine $(1 \times 3 \mathrm{~mL})$, dried over $\mathrm{Na}_{2} \mathrm{SO}_{4}$, filtered and concentrated in vacuo. The crude material was purified by flash chromatography (petroleum ether/ethyl acetate $5: 1$ ) to yield 1,4-bis(phenyltellanyl)butane-2,3-diol 3c (98 mg, 79\%). ${ }^{1} \mathrm{H}$ NMR (400 MHz, $\left.\mathrm{CDCl}_{3}\right): \delta(\mathrm{ppm}) 2.96(2 \mathrm{H}, \mathrm{bd}$, $J=5.0 \mathrm{~Hz}, \mathrm{OH}), 3.05\left(2 \mathrm{H}, \mathrm{dd}, J=5.0,12.1 \mathrm{~Hz}, \mathrm{CH}_{\mathrm{a}} \mathrm{H}_{\mathrm{b}} \mathrm{Te}\right), 3.11$ $\left(2 \mathrm{H}, \mathrm{dd}, J=7.5,12.1 \mathrm{~Hz}, \mathrm{CH}_{\mathrm{a}} \mathbf{H}_{\mathbf{b}} \mathrm{Te}\right), 3.75-3.84(2 \mathrm{H}, \mathrm{m}, \mathrm{CHOH})$, 7.16-7.20 (4H, m), 7.26-7.30 (2H, m), 7.70-7.73 (4H, m). ${ }^{13} \mathrm{C}$ NMR (100 MHz, $\left.\mathrm{CDCl}_{3}\right): \delta$ (ppm) 15.3 (CH2Te), 73.6, 111.5 (CTe), 127.8, 129.3, 138.4. ${ }^{125} \mathrm{Te}$ NMR (126 MHz, $\mathrm{CDCl}_{3}$ ): $\delta$ (ppm) 394.1. MS (ESI positive) $m / z(\%): 520[\mathrm{M}+\mathrm{Na}]^{+},(100)$. Elemental analysis: $\mathrm{C}_{16} \mathrm{H}_{18} \mathrm{O}_{2} \mathrm{Te}_{2}$ calcd $\mathrm{C} 38.63 \%, \mathrm{H} 3.65 \%$. Found: C $38.56 \%$, H 3.67\%.

(S)-4-Methyl- $N$-(3-methyl-1-(phenyltellanyl)butan-2-yl)benzenesulfonamide (5). $\mathrm{NaBH}_{4}(28 \mathrm{mg}, 0.75 \mathrm{mmol}, 3.0$ eq.) was portionwise added to a solution of diphenyl ditelluride $(102 \mathrm{mg}, 0.25 \mathrm{mmol}$, 1.0 eq.) in EtOH $(2 \mathrm{~mL})$ at $0{ }^{\circ} \mathrm{C}$ under inert atmosphere $\left(\mathrm{N}_{2}\right)$.
After $30 \mathrm{~min}$, a solution of (S)-2-isopropyl-1-tosylaziridine $(117 \mathrm{mg}, 0.50 \mathrm{mmol}, 2.0$ eq.) in dry THF $(0.5 \mathrm{~mL})$ was slowly added and the reaction mixture was warmed at RT and stirred for $6 \mathrm{~h}$. Afterwards, saturated aq. $\mathrm{NH}_{4} \mathrm{Cl}(3 \mathrm{~mL})$ was added and the organic phase was extracted with $\mathrm{Et}_{2} \mathrm{O}(2 \times 5 \mathrm{~mL})$, washed with brine $(1 \times 3 \mathrm{~mL})$, dried over $\mathrm{Na}_{2} \mathrm{SO}_{4}$, filtered and concentrated in vacuo. The crude material was purified by flash chromatography (petroleum ether/ $\mathrm{Et}_{2} \mathrm{O}$ 7:1) to yield $(S)$-4-methyl- $N$-(3-methyl-1(phenyltellanyl)butan-2-yl)benzenesulfonamide 5 (173 $\mathrm{mg}, 78 \%$ ). ${ }^{1} \mathrm{H}$ NMR (400 MHz, $\left.\mathrm{CDCl}_{3}\right) \delta$ (ppm): $0.74(3 \mathrm{H}, \mathrm{d}, J=6.7 \mathrm{~Hz}), 0.80$ $(3 \mathrm{H}, \mathrm{d}, J=6.8 \mathrm{~Hz}), 1.78-1.90(1 \mathrm{H}, \mathrm{m}), 2.38\left(3 \mathrm{H}, \mathrm{s}, \mathrm{CH}_{3}\right), 2.72$ $\left(1 \mathrm{H}, \mathrm{dd}, J=6.5,12.1 \mathrm{~Hz}, \mathrm{CH}_{\mathrm{a}} \mathrm{H}_{\mathrm{b}} \mathrm{Te}\right), 3.10(1 \mathrm{H}, \mathrm{dd}, J=4.6,12.1 \mathrm{~Hz}$, $\left.\mathrm{CH}_{\mathrm{a}} \mathbf{H}_{\mathrm{b}} \mathrm{Te}\right), 3.18-3.20$ (1H, m, CHNH), $4.75(1 \mathrm{H}, \mathrm{d}, J=8.8 \mathrm{~Hz}, \mathrm{NH})$, 7.17-7.20 (4H, m), 7.29-7.33 (1H, m), 7.61-7.63 (4H, m). ${ }^{13} \mathrm{C}$ NMR $\left(100 \mathrm{MHz}, \mathrm{CDCl}_{3}\right) \delta(\mathrm{ppm}): 14.6\left(\mathrm{CH}_{2} \mathrm{Te}\right), 17.5,19.2,32.3,59.3$, 110.9 (TeC), 127.0, 128.0, 129.3, 129.6, 137.8, 138.8, 143.2. MS (ESI positive) $\mathrm{m} / z(\%): 468[\mathrm{M}+\mathrm{Na}]^{+},(100)$. Elemental analysis: $\mathrm{C}_{18} \mathrm{H}_{23} \mathrm{NO}_{2} \mathrm{STe}$ calcd $\mathrm{C} 48.58 \%$, H $5.21 \%$, N 3.15\%. Found: $\mathrm{C}$ $48.49 \%$, H $5.23 \%$, N $3.17 \%$.

tert-Butyl (S)-(3-methyl-1-(phenyltellanyl)butan-2-yl)carbamate (8). $\mathrm{NaBH}_{4}$ (28 mg, $0.75 \mathrm{mmol}, 3.0$ eq.) was portionwise added to a solution of diphenyl ditelluride ( $102 \mathrm{mg}, 0.25 \mathrm{mmol}, 1.0 \mathrm{eq}$.) in EtOH $(2 \mathrm{~mL})$ at $0{ }^{\circ} \mathrm{C}$ under inert atmosphere $\left(\mathrm{N}_{2}\right)$. After $30 \mathrm{~min}$, a solution of tert-butyl $(S)$-2-isopropylaziridine-1-carboxylate $(93 \mathrm{mg}$, $0.50 \mathrm{mmol}, 2.0$ eq.) in dry THF $(0.5 \mathrm{~mL})$ was slowly added and the reaction mixture was warmed at RT and stirred for $6 \mathrm{~h}$. Afterwards, saturated aq. $\mathrm{NH}_{4} \mathrm{Cl}(3 \mathrm{~mL})$ was added and the organic phase was extracted with $\mathrm{Et}_{2} \mathrm{O}(2 \times 5 \mathrm{~mL})$, washed with brine $(1 \times 3 \mathrm{~mL})$, dried over $\mathrm{Na}_{2} \mathrm{SO}_{4}$, filtered and concentrated in vacuo. The crude material was purified by flash chromatography (petroleum ether/ ethyl acetate $8: 1$ ) to yield tert-butyl $(S)$-(3-methyl-1-(phenyltellanyl)butan-2-yl)carbamate 8 (132 mg, 68\%). ${ }^{1} \mathrm{H}$ NMR (400 MHz, $\mathrm{CDCl}_{3}$ ): $\delta$ (ppm) $0.88(6 \mathrm{H}$, ap t, $J=6.5 \mathrm{~Hz}), 1.42(9 \mathrm{H}, \mathrm{s}), 1.71-1.83(1 \mathrm{H}, \mathrm{m})$, $3.06\left(1 \mathrm{H}, \mathrm{dd}, J=4.8,12.1 \mathrm{~Hz}, \mathrm{CH}_{\mathrm{a}} \mathrm{H}_{\mathrm{b}} \mathrm{Te}\right), 3.13(1 \mathrm{H}, \mathrm{dd}, J=7.2,12.1$ $\left.\mathrm{Hz}, \mathrm{CH}_{\mathrm{a}} \mathbf{H}_{\mathrm{b}} \mathrm{Te}\right), 3.58-3.65(1 \mathrm{H}, \mathrm{m}, \mathrm{CHNH}), 4.56(1 \mathrm{H}, \mathrm{d}, J=9.1 \mathrm{~Hz}$, $\mathrm{NH}), 7.17-7.21(2 \mathrm{H}, \mathrm{m}), 7.25-7.28(1 \mathrm{H}, \mathrm{m}), 7.74-7.77(2 \mathrm{H}, \mathrm{m})$. ${ }^{13} \mathrm{C}$ NMR (100 MHz, $\left.\mathrm{CDCl}_{3}\right): \delta$ (ppm) $15.1\left(\mathrm{CH}_{2} \mathrm{Te}\right), 18.1,19.5,28.4$, $33.3,56.3,79.2,111.6,127.7,129.2,138.7,155.5 .{ }^{125} \mathrm{Te}$ NMR (126 MHz, $\mathrm{CDCl}_{3}$ ): $\delta$ (ppm) 398.0. MS (ESI positive) $\mathrm{m} / \mathrm{z}$ (\%): 414 $[\mathrm{M}+\mathrm{Na}]^{+},(100)$. Elemental analysis: $\mathrm{C}_{16} \mathrm{H}_{25} \mathrm{NO}_{2}$ Te calcd $\mathrm{C} 49.15 \%$, H 6.45\%, N 3.58\%. Found: C 49.22\%, H 6.43\%, N 3.56\%.

(S)-3-Methyl-1-(phenyltellanyl)butan-2-amine (9). A solution of acetyl chloride (150 $\mu \mathrm{L}, 2.11 \mathrm{mmol}, 15$ eq.) in $\mathrm{MeOH}(2 \mathrm{~mL})$ was slowly added to a solution of tert-butyl ( $S$ )-(3-methyl-1(phenyltellanyl)butan-2-yl)carbamate 8 (70 mg, $0.18 \mathrm{mmol}$, 1.0 eq.) in $\mathrm{MeOH}(2 \mathrm{~mL})$ at $0{ }^{\circ} \mathrm{C}$ under inert atmosphere $\left(\mathrm{N}_{2}\right)$. The reaction mixture was stirred at $0{ }^{\circ} \mathrm{C}$ for $6 \mathrm{~h}$ and the solvent was removed under vacuum to afford the crude product. Flash column chromatography (petroleum ether/ethyl acetate 1:3) gave (S)-3-methyl-1-(phenyltellanyl)butan-2-amine 9 (46 mg, 88\%). ${ }^{1} \mathrm{H}$ NMR (400 MHz, $\left.\mathrm{CDCl}_{3}\right): \delta(\mathrm{ppm}) 0.91(6 \mathrm{H}$, ap d, $J=6.8 \mathrm{~Hz})$, 1.61-1.73 (1H, m), 2.72-2.76 (1H, m, CHNH), 2.97 (1H, dd, $J=9.3$, $\left.11.6 \mathrm{~Hz}, \mathrm{CH}_{\mathrm{a}} \mathrm{H}_{\mathrm{b}} \mathrm{Te}\right), 3.11\left(1 \mathrm{H}, \mathrm{dd}, J=4.0,11.6 \mathrm{~Hz}, \mathrm{CH}_{\mathrm{a}} \mathbf{H}_{\mathbf{b}} \mathrm{Te}\right), 7.17-$ 7.21 (2H, m), 7.24-7.29 (1H, m), 7.71-7.75 (2H, m). ${ }^{13} \mathrm{C}$ NMR (100 MHz, $\left.\mathrm{CDCl}_{3}\right): \delta(\mathrm{ppm}) 17.9\left(\mathrm{CH}_{2} \mathrm{Te}\right), 18.1,19.4,34.7,57.7$, 112.3, 127.5, 129.1, 138.3. ${ }^{125} \mathrm{Te}$ NMR (126 MHz, $\left.\mathrm{CDCl}_{3}\right): \delta(\mathrm{ppm})$ 
403.1. MS (ESI positive) $m / z$ (\%): $314[\mathrm{M}+\mathrm{Na}]^{+}$, (100). Elemental analysis: $\mathrm{C}_{11} \mathrm{H}_{17} \mathrm{NTe}$ calcd $\mathrm{C} 45.42 \%$, H 5.89\%, N 4.82\%. Found: C $45.47 \%, \mathrm{H} 5.86 \%$, N $4.79 \%$.

Allyl(1-(benzyloxy)-3-(phenyltellanyl)propan-2-yl)sulfane (11). $\mathrm{NaBH}_{4}$ (28 mg, $0.75 \mathrm{mmol}, 3.0$ eq.) was portionwise added to a solution of diphenyl ditelluride (102 mg, $0.25 \mathrm{mmol}, 1.0$ eq.) in EtOH $(2 \mathrm{~mL})$ at $0{ }^{\circ} \mathrm{C}$ under inert atmosphere $\left(\mathrm{N}_{2}\right)$. After $30 \mathrm{~min}$, 2-((benzyloxy)methyl)thiirane (99 $\mathrm{mg}, 0.55 \mathrm{mmol}, 2.2 \mathrm{eq}$.) was slowly added and the reaction mixture was stirred at $0{ }^{\circ} \mathrm{C}$ and the reaction progress was monitored by TLC. When the starting thiirane had completely reacted, allyl bromide $(54 \mu \mathrm{L}, 0.625 \mathrm{mmol}$, 2.5 eq.) was dropwise added and the reaction mixture was stirred at $0{ }^{\circ} \mathrm{C}$ for 30 minutes and then warmed at RT and stirred for $2 \mathrm{~h}$. Afterwards, saturated aq. $\mathrm{NH}_{4} \mathrm{Cl}(5 \mathrm{~mL})$ was added and the organic phase was extracted with $\mathrm{Et}_{2} \mathrm{O}(2 \times 5 \mathrm{~mL})$, washed with brine $(1 \times 5 \mathrm{~mL})$, dried over $\mathrm{Na}_{2} \mathrm{SO}_{4}$, filtered and concentrated in vacuo. The crude material was purified by flash chromatography (petroleum ether/diethyl ether 15:1) to yield allyl(1-(benzyloxy)-3(phenyltellanyl)propan-2-yl)sulfane 11 (162 mg, 76\%). ${ }^{1} \mathrm{H}$ NMR (400 $\left.\mathrm{MHz}, \mathrm{CDCl}_{3}\right): \delta(\mathrm{ppm}) 3.11-3.19\left(3 \mathrm{H}, \mathrm{m}, \mathrm{SCH} \mathrm{CH}_{2}=\mathrm{CH}_{2}\right.$ and CHS overlapped), $3.24\left(1 \mathrm{H}, \mathrm{dd}, J=5.4,11.8 \mathrm{~Hz}, \mathrm{CH}_{\mathbf{a}} \mathrm{H}_{\mathrm{b}} \mathrm{Te}\right)$, $3.34\left(1 \mathrm{H}, \mathrm{dd}, J=8.0,11.8 \mathrm{~Hz}, \mathrm{CH}_{\mathrm{a}} \mathbf{H}_{\mathbf{b}} \mathrm{Te}\right), 3.57(1 \mathrm{H}, \mathrm{dd}, J=7.0$, $\left.9.7 \mathrm{~Hz}, \mathrm{CH}_{\mathrm{a}} \mathrm{H}_{\mathrm{b}} \mathrm{O}\right), 3.72\left(1 \mathrm{H}, \mathrm{dd}, J=4.7,9.7 \mathrm{~Hz}, \mathrm{CH}_{\mathrm{a}} \mathrm{H}_{\mathrm{b}} \mathrm{O}\right), 4.46$ (2H, ap s, $\left.\mathrm{CH}_{2} \mathrm{Ph}\right), 4.95-5.01(2 \mathrm{H}, \mathrm{m}), 5.70-5.82(1 \mathrm{H}, \mathrm{m}), 7.14-7.18$ $(2 \mathrm{H}, \mathrm{m}), 7.23-7.35$ (6H, m), 7.72-7.75 (2H, m). ${ }^{13} \mathrm{C}$ NMR $(100 \mathrm{MHz}$, $\left.\mathrm{CDCl}_{3}\right): \delta(\mathrm{ppm}) 12.9\left(\mathrm{CH}_{2} \mathrm{Te}\right), 34.5,45.1,73.073 .1,112.9$ (CTe), 117.2, 127.5, 127.57, 127.58, 128.3, 129.1, 134.3, 137.9, 138.3. ${ }^{125} \mathrm{Te}$ NMR (126 MHz, $\mathrm{CDCl}_{3}$ ): $\delta$ (ppm) 456.2. MS (ESI positive) $\mathrm{m} / z$ (\%): $449[\mathrm{M}+\mathrm{Na}]^{+},(100)$. Elemental analysis: $\mathrm{C}_{19} \mathrm{H}_{22}$ OSTe calcd $\mathrm{C}$ $53.56 \%$, H 5.21\%. Found: C 53.62\%, H 5.19\%.

\section{GPx-like catalytic activity measurements}

Glutathione peroxidase-like activity was evaluated following reported procedure (see ESI $\dagger$ for details).

\section{Conflicts of interest}

The authors declare no conflicts of interest.

\section{Notes and references}

1 (a) C. W. Nogueira and J. B. T. Rocha, Arch. Toxicol., 2011, 85, 1313; (b) K. P. Bhabak and G. Mugesh, Acc. Chem. Res., 2010, 43, 1408; (c) C. W. Nogueira, G. Zeni and J. B. T. Rocha, Chem. Rev., 2004, 104, 6255 and references cited therein.

2 (a) J. K. Andersen, Nat. Rev. Neurosci., 2004, 5, S18; (b) R. C. S. Seet, C.-Y. J. Lee, E. C. H. Lima, J. J. H. Tan, A. M. L. Quek, W.-L. Chong, W.-F. Looi, S.-H. Huang, H. Wang, Y.-H. Chand and B. Halliwell, Free Radical Biol. Med., 2010, 48, 560 .

3 (a) B. M. Gay, C. Luchese, C. W. Nogueira, P. Wendler, A. Macedo and A. A. Dos Santos, J. Enzyme Inhib. Med. Chem., 2010, 25, 467; (b) L. Engman, M. J. Laws, C. H. Schiesser and L. M. Zugaro, J. Org. Chem., 1999, 64, 6764; (c) S. Kumar, L. Engman, L. Valgimigli, R. Amorati, M. G. Fumo and G. F. Pedulli, J. Org. Chem., 2007, 72, 6056. 4 Inter Alia (a) B. J. Bhuyan and G. Mugesh, in Organoselenium Chemistry. Synthesis and Reactions, ed. T. Wirth, Wiley-VCH Verlag \& Co, Weinheim, Germany, 2012, vol. 8, pp. 361-379 and references cited therein; (b) S. Yoshida, F. Kumakura, I. Komatsu, K. Arai, Y. Onuma, H. Hojo, B. G. Singh, K. I. Priyadarsini and M. Iwaoka, Angew. Chem., Int. Ed., 2011, 50, 2125; (c) F. Kumakura, B. Mishra, K.-I. Priyadarsini and M. Iwaoka, Eur. J. Org. Chem., 2010, 440; (d) T.-G. Back, Can. J. Chem., 2009, 87, 1657; (e) E. E. Alberto, L. C. Soares, J. H. Sudati, A. C. A. Borges, J. B. T. Rocha and A. L. Braga, Eur. J. Org. Chem., 2009, 4211; $(f)$ A. Muller, E. Cadenas, P. Graf and H. Sies, Biochem. Pharmacol., 1984, 33, 3235; (g) K.-P. Bhabak and G. Mugesh, Chem. - Eur. J., 2007, 13, 4594.

5 For a review see: (a) A. J. Pacula, F. Mangiavacchi, L. Sancineto, E. J. Lenardao, J. Scianowski and C. Santi, Curr. Chem. Biol., 2015, 9, 97; (b) C. Santi, C. Tidei, C. Scalera, M. Piroddi and F. Galli, Curr. Chem. Biol., 2013, 7, 25; (c) E. E. Alberto, V. Nascimento and A. L. Braga, J. Braz. Chem. Soc., 2010, 21, 2032.

6 (a) T. Lin, Z. Ding, N. Li, J. Xu, G. Luo, J. Liu and J. Shen, Carcinogenesis, 2010, 32, 154; (b) L. Tiano, D. Fedeli, A. M. Santroni, M. Villarini, L. Engman and G. Falcioni, Mutat. Res., 2000, 464, 269; (c) R. H. Al-Asadi, W. A. Al-Masoudi and K. S. Abdual-Rassol, Asian J. Chem., 2016, 28, 1171; (d) R. Saxena and P. Sharma, Ind. J. Pharm. Biol. Res., 2015, 3, 1; (e) G. I. Giles, F. H. Fry, K. M. Tasker, A. L. Holme, C. Peers, K. N. Green, L. O. Klotz, H. Sies and C. Jacob, Org. Biomol. Chem., 2003, 1, 4317.

7 M. Bortoli, M. Torsello, F. M. Bickelhaupt and L. Orian, ChemPhysChem, 2017, 18, 2990.

8 L. Engman, D. Stern and M. Pelcman, J. Org. Chem., 1994, 59, 1973.

9 L. Engman, D. Stern, H. Frisell, K. Vessman, M. Berglund, B. Ek and C. M. Andersson, Bioorg. Med. Chem., 1995, 3, 1255.

10 L. Engman, D. Stern, I. A. Cotgreave and C. M. Andersson, J. Am. Chem. Soc., 1992, 114, 9737.

11 J. Malmström, M. Jonsson, I. A. Cotgreave, L. Hammarström, M. Sjödin and L. Engman, J. Am. Chem. Soc., 2001, 123, 3434.

12 A. L. Braga, E. E. Alberto, L. C. Soares, J. B. T. Rocha, J. H. Sudati and D. H. Roos, Org. Biomol. Chem., 2009, 7, 43. 13 A. Jiao, N. Yang, J. Wang, X. Xu and Z. Jin, J. Inclusion Phenom. Macrocyclic Chem., 2013, 75, 155.

14 V. P. Singh, J. F. Poon and L. Engman, Org. Lett., 2013, 15, 6274.

15 S. F. Fonseca, D. B. Lima, D. Alves, R. G. Jacob, G. Perin, E. J. Lenardão and L. Savegnago, New J. Chem., 2015, 39, 3043.

16 P. C. Nobre, E. L. Borges, C. M. Silva, A. M. Casaril, D. M. Martinez, E. J. Lenardão, D. Alves, L. Savegnago and G. Perin, Bioorg. Med. Chem., 2014, 22, 6242.

17 A. S. Hodage, P. P. Phadnis, A. Wadawale, K. I. Priyadarsini and V. K. Jain, Org. Biomol. Chem., 2011, 9, 2992. 
18 Y. You, K. Ahsan and M. R. Detty, J. Am. Chem. Soc., 2003, 125, 4918.

19 (a) D. Tanini, A. Caperucci and A. Degl'Innocenti, Eur. J. Org. Chem., 2015, 357; (b) A. Capperucci, D. Tanini, C. Borgogni and A. Degl'Innocenti, Heteroat. Chem., 2014, 25, 678.

20 A. Capperucci, C. Tiberi, S. Pollicino and A. Degl'Innocenti, Tetrahedron Lett., 2009, 50, 2808.

21 D. Tanini, V. D’Esopo, D. Chen, G. Barchielli and A. Capperucci, Phosphorus, Sulfur Silicon Relat. Elem., 2017, 192, 166.

22 (a) A. Angeli, D. Tanini, A. Capperucci and C. T. Supuran, ACS Med. Chem. Lett., 2017, 8, 1213; (b) A. Angeli, D. Tanini, C. Viglianisi, L. Panzella, A. Capperucci, S. Menichetti and C. T. Supuran, Bioorg. Med. Chem., 2017, 25, 2518.

23 D. Tanini, A. Grechi, S. Dei, E. Teodori and A. Capperucci, Tetrahedron, 2017, 73, 5646.

24 A. Angeli, D. Tanini, A. Capperucci and C. T. Supuran, Bioorg. Chem., 2018, 76, 268.

25 (a) M. Iwaoka and F. Kumakura, Phosphorus, Sulfur Silicon Relat. Elem., 2008, 183, 1009; (b) F. Kumakura, B. Mishra, K. I. Priyadarsini and M. Iwaoka, Eur. J. Org. Chem., 2010, 440.

26 M. Iwaoka and S. Tomoda, J. Am. Chem. Soc., 1994, 116, 2557.
27 (a) P. Pascual, E. Martinez-Lara, J. A. Bàrcena, J. Lòpez-Barca and F. Toribio, J. Chromatogr., Biomed. Appl., 1992, 581, 49; (b) A. Angeli, D. Tanini, T. S. Peat, L. Di Cesare Mannelli, G. Bartolucci, A. Capperucci, C. Ghelardini, C. T. Supuran and F. Carta, ACS Med. Chem. Lett., 2017, 8, 963.

28 S. K. Tripathi, U. Patel, D. Roy, R. B. Sunoj, H. B. Singh, G. Wolmershäuser and R. J. Butcher, J. Org. Chem., 2005, 70, 9237.

29 (a) V. Nascimento, E. E. Alberto, D. W. Tondo, D. Dambrowski, M. R. Detty, F. Nome and A. L. Braga, J. Am. Chem. Soc., 2012, 134, 138; $(b)$ M. R. Detty, A. E. Friedman and A. R. Oseroff, J. Org. Chem., 1994, 59, 8245.

30 D. J. Pascoe, K. B. Ling and S. L. Cockroft, J. Am. Chem. Soc., 2017, 139, 15160.

31 (a) K. Selvakumar, P. Shah, H. B. Singh and R. J. Butcher, Chem. - Eur. J., 2011, 17, 12741; (b) K. P. Bhabak and G. Mugesh, Chem. - Eur. J., 2008, 14, 8640.

32 R. L. Pederson, K. K. C. Liu, J. F. Rutan, L. Chen and C. H. Wong, J. Org. Chem., 1990, 55, 4897.

33 (a) M. B. Bieber and M. C. F. de Araujo, Molecules, 2002, 7, 902; (b) M. B. Berry and D. Craig, Synlett, 1992, 41; (c) H. M. I. Osborn and J. Sweeney, Tetrahedron: Asymmetry, 1997, 8, 1693. 